\title{
Commentary
}

\section{Applying the Hierarchy of Hazard Control to Regulation of Sound Levels in Entertainment Venues}

\section{Elizabeth Francis Beach ${ }^{1,2, *, \oplus, \text { Robert Cowan }}{ }^{2,5}$, Johannes Mulder ${ }^{3}$ and Ian O'Brien ${ }^{4}$}

${ }^{1}$ National Acoustic Laboratories, Level 5, 16 University Avenue, Macquarie University, NSW 2109, Australia; 2The HEARing CRC, 550 Swanston St, Carlton, VIC 3053, Australia; ${ }^{3}$ Murdoch University, 90 South St, Murdoch, WA 6150, Australia; ${ }^{4}$ Queensland Conservatorium of Music, Griffith University, 140 Grey St, South Brisbane, QLD 4101, Australia; ${ }^{2}$ University of Melbourne, 550 Swanston St, Carlton, VIC 3053, Australia

*Author to whom correspondence should be addressed. Tel: +61-2-9412-6983; e-mail: elizabeth.beach@nal.gov.au

Submitted 9 November 2019; revised 28 December 2019; editorial decision 3 February 2020; revised version accepted 9 February 2020.

\begin{abstract}
Excessive sound levels at events where amplified music is a central element pose a risk to hearing. Whereas noise exposure in the workplace has been recognized as a hazard for over a century, the potential harm resulting from recreational sound exposure has only become apparent in recent years. In occupational settings where sound levels are high, employers are required to implement risk-mitigation strategies to reduce sound exposure and protect employees in accordance with the hierarchy of controls. In principle, this same risk management approach can be applied to entertainment venues. In this paper we discuss how the measures stipulated in various policies and regulations aimed at protecting the hearing of audience members at entertainment venues fit within the hierarchy of controls. We compare the relative likely effectiveness of each of the measures and outline how the particular characteristics of entertainment venues impact on the practical application of these measures.
\end{abstract}

Keywords: noise; noise and leisure; risk management

\section{Introduction}

Attending events where amplified music is a central element, such as concert arenas, nightclubs and music venues, is a pleasurable leisure activity, enjoyed by thousands of people on any given day. Like many recreational pursuits, consumption of loud music involves both rewards and risks (Blesser, 2007; Welch and Fremaux, 2017a). As sound levels increase, the risk to hearing also increases and the potential harm posed by this hazard has become the subject of scientific research over the past several decades (Hanson and Fearn, 1975; Meyer-Bisch, 1996; Kraaijenga et al., 2018). In the workplace, where 
noise exposure has been recognized as a hazard for over a century, risk managers implement risk-mitigation strategies in accordance with the hierarchy of controls. These range from elimination, which is considered most effective, to the use of personal protective equipment-the least effective strategy (Boyle, 2008; Fig. 1).

In principle, this same risk management approach can be applied to entertainment venues to minimize the risks to attendees' hearing associated with loud sound levels. Controls may include provision of earplugs (personal protective equipment); restricting access to loudspeakers (engineering controls) through to substitution of the risk by implementing active noise control at the source. Although individual music venues may elect to implement some or all of these measures, in order to effect systemic change, ideally, the measures would be implemented through policies and guidelines, regulation, or legislation.

The purpose of this paper is to discuss how the measures set out in current policies and regulations in countries across the world to protect the hearing of audience members within entertainment venues fit within the hierarchy of controls as a way of assessing their likely effectiveness. A number of European countries have introduced detailed regulations and policies in this regard, likely influenced by the noise exposure limits set out in the European Directive 2003/10/EC (European Parliament and Council, 2003). Some other countries, such as Mexico, USA, Nicaragua and Trinidad and Tobago also have regulations relating to sound levels in entertainment venues but these are less detailed than those in place in Europe. See Table 1.

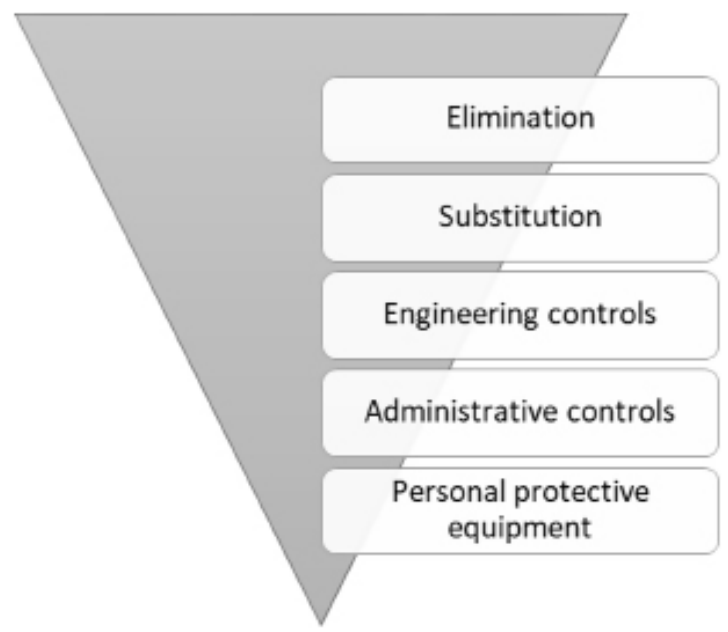

Figure 1. Hierarchy of controls (adapted from NIOSH, https:// www.cdc.gov/niosh/topics/hierarchy/default.html).
A review of the regulations shows that they commonly include the following measures:

- A sound level limit

- Real-time sound level monitoring

- Provision of warnings-at the venue and on tickets and marketing materials

- Provision of earplugs-free or at low cost

- Ensuring attendees can access quiet zones or rest areas

- Restricting audience access to loudspeakers

This suite of six measures includes methods that range from most to least effective within the hierarchy of hazard controls. See Fig. 2. Elimination and substitution are regarded as the most effective strategies, and while elimination of the hazard (loud music) is not feasible in this context, long periods of high-intensity sound can be substituted with sound of lower intensity and/or shorter duration. Warnings are classified as an administrative control, whereas restricting access to speakers and providing rest areas are engineering controls, in which people are isolated from the hazard. Finally, provision of earplugs is consistent with the method of control that is regarded as least effective: use of personal protective equipment.

A set of measures such as these would strike a balance between a regulatory top-down approach and a more autonomous bottom-up approach. On the one hand, policymakers, knowing the risks involved, have a duty of care to act to limit sound levels in order to reduce the risk to attendees' hearing at entertainment venues (especially considering that many attendees may be unaware of the potential for harm). On the other hand, one could argue that audience members should take responsibility

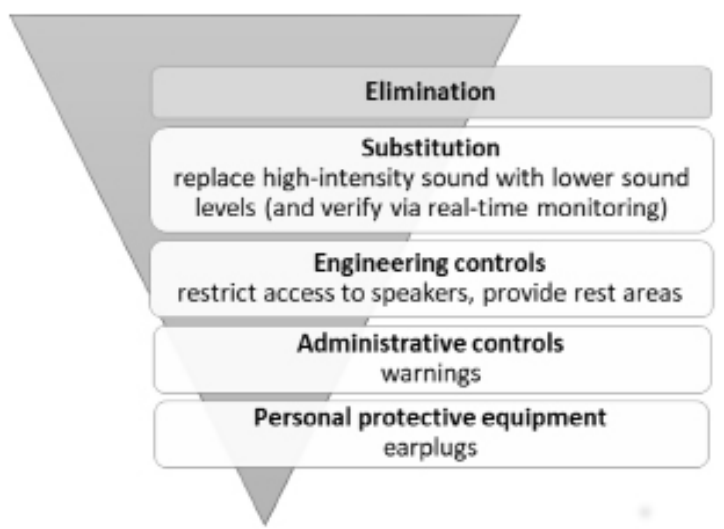

Figure 2. Recommended hierarchy of controls for entertainment venues. 


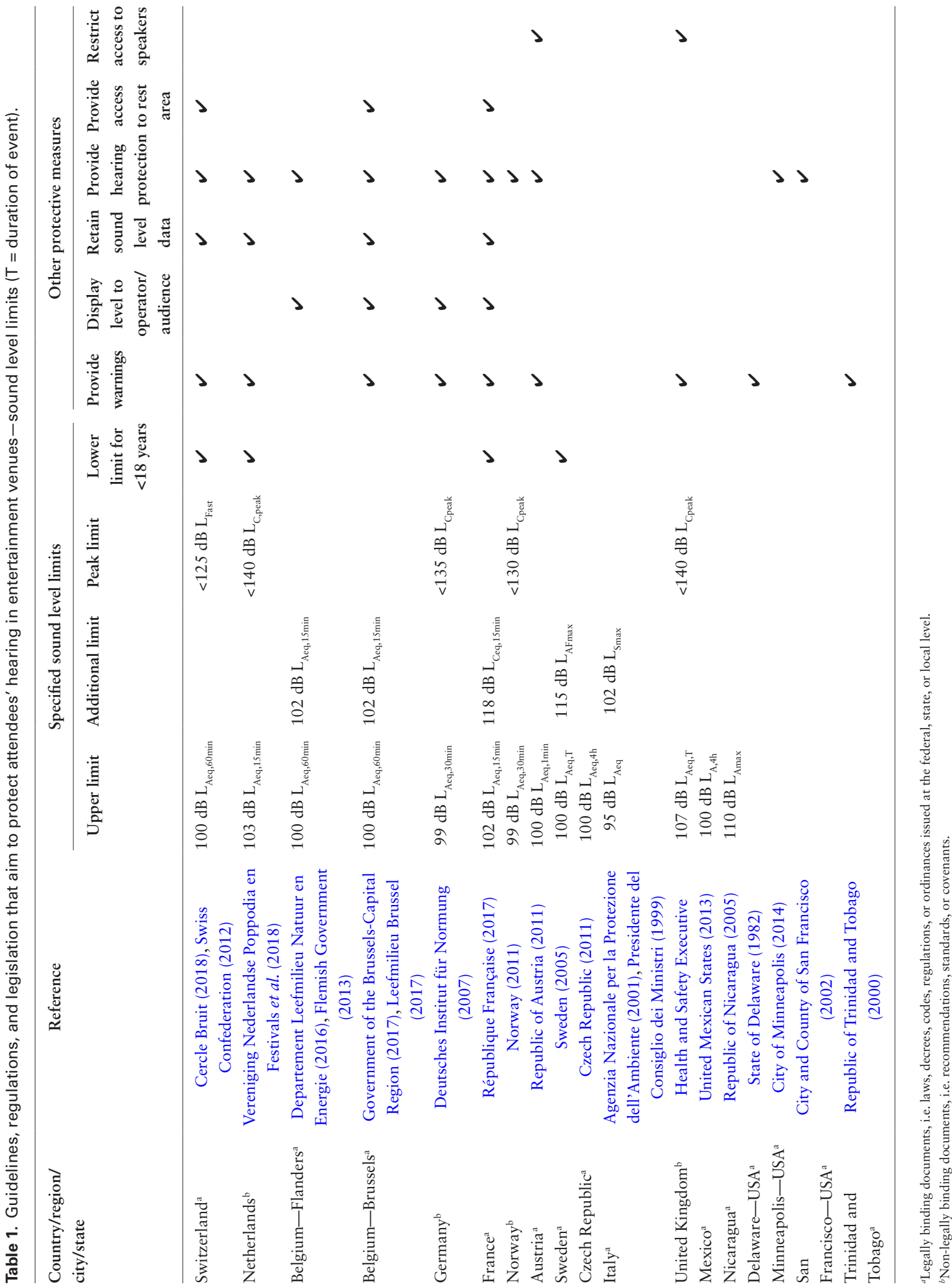


for their hearing health and wellbeing. Under the model proposed here, the mandated sound level limit would act to control the risk level, but at the same time, audience members would be informed of the potential risks via appropriate warnings. This will enable them to make an informed decision about how to manage their own sound exposure and when to take protective action, such as using earplugs or taking breaks in quiet zones. The rationale for including each of the recommended elements is described below.

\section{Substitution}

\section{Sound level limits}

Deciding on an appropriate evidence-based sound level limit as a substitute for the high-intensity sound levels typically found in entertainment venues is not straightforward. In the workplace, the daily exposure limit is typically $85 \mathrm{~dB}$ $\mathrm{L}_{\text {Aeq,8h }}$ with a 3-dB exchange rate (NIOSH, 1998), which means that when the sound level increases by $3 \mathrm{~dB}$, exposure time must be halved to maintain the equivalent level of risk. In recreational settings, there is debate as to whether this criterion should be used, with some authors questioning whether or not musical and industrial exposures have an equivalent impact on hearing (Lindgren and Axelsson, 1983; Strasser et al., 2003). Another complicating issue is duration of exposure. Unlike the workplace, where workers' exposure periods are relatively predictable and regular and damage-risk criteria can be formulated on this basis, audience members' attendance at entertainment venues is unpredictable, irregular, and highly variable between individuals. Neitzel and Fligor (2017) considered both of these issues and suggested that $83 \mathrm{~dB} \mathrm{~L} \mathrm{Leq}, 8 \mathrm{~h}_{\text {w }}$ would be an appropriate recreational exposure. (Under the equal-energy principle, this is equivalent to $86 \mathrm{~dB} \mathrm{~L}_{\text {Aeq,4h }}$ or $89 \mathrm{~dB} \mathrm{~L}_{\text {Aeq,2h }}$.) This recommendation assumes that musical and industrial sound are equally impactful and takes into account that lifetime recreational sound exposure begins in childhood, and therefore extends beyond the 40-year exposure period assumed in workplace damage-risk criteria. The authors argued that $83 \mathrm{~dB} \mathrm{~L}_{\text {Aeq,8h }}$ would be sufficiently protective of the vast majority of people, and yet it is a great deal lower than typical sound levels found in music venues, and unlikely to be accepted as a sound level limit by the music industry.

The review of the various European sound level limits presented in Table 1 suggests an upper level of around $100 \mathrm{~dB} \mathrm{~L}_{\text {Aeq }}$ is more likely to be accepted by the music industry. This figure is consistent with sound levels that are likely to meet the socio-cultural expectations of audiences and performers (Parnell and Hartcher, 2017; Welch and Fremaux, 2017b). Importantly, such a level would also meet the preference of many audience members who research has repeatedly shown would prefer sound levels that are lower than the very high-intensity levels often encountered in nightclubs and live music venues (Mercier and Hohmann, 2002; Gilles et al., 2014; Johnson et al., 2014; Beach and GIlliver, 2019).

It is important to note that setting a sound level limit of $100 \mathrm{~dB} \mathrm{~L}_{\text {Aeq }}$ does not constitute a declaration that this is 'safe'. Rather, regulations should include a statement advising that the prescribed level should not be considered 'safe', and that risk to an individual's hearing will vary according to the time an individual spends in a venue and the amount of exposure that one receives from other sources. For example, the Dutch covenant (Vereniging Nederlandse Poppodia en Festivals et al., 2018) that sets out guidelines for the music industry in the Netherlands states:

\section{Translation: 'The parties to the agreement realize that the [prescribed] noise levels... are not absolutely safe for every individual. Hearing damage can occur under the recommended sound level... Therefore, the parties to the covenant regard it as important to inform visitors and professionals how to reduce the risk of hearing damage.' page 6}

Requiring that venues substitute current levels with lower sound level limits that do not exceed $100 \mathrm{~dB} \mathrm{~L}_{\text {Aeq }}$ would at the very least reduce the prevalence of loud music events that exceed this level. As sound levels increase, the risk of hearing damage increases exponentially and when the sound level exceeds $100 \mathrm{~dB} \mathrm{~L}_{\mathrm{Aeq}}$ the exposure values escalate quickly. For example, at $100 \mathrm{~dB}$ $\mathrm{L}_{\text {Aeq }}$, a 4-h event is equivalent to $16 \mathrm{~Pa}^{2} \mathrm{~h}$; at $103 \mathrm{~dB} \mathrm{~L}_{\text {Aeq }}$ exposure increases to $32 \mathrm{~Pa}^{2} \mathrm{~h}$; at $106 \mathrm{~dB} \mathrm{~L}_{\text {Aeq }}$, it's 64 $\mathrm{Pa}^{2} \mathrm{~h}$; and at $109 \mathrm{~dB} \mathrm{~L}_{\text {Aeq }}$, exposure reaches $128 \mathrm{~Pa}^{2} \mathrm{~h}$. Setting a limit of around $100 \mathrm{~dB} \mathrm{~L}_{\text {Aeq }}$, will not prevent the risk of harm but it would almost certainly reduce the risk of harm.

There is a risk that setting a sound level limit of $100 \mathrm{~dB} \mathrm{~L} \mathrm{Aeq}_{\text {eq }}$ will result in a 'drift' towards this level, including events that were previously below $100 \mathrm{~dB}$ $\mathrm{L}_{\text {Aeq }}$. There is some evidence of this in preliminary data presented by McGinnity et al. (2018) in which a sound level limit of $98 \mathrm{~dB} \mathrm{~L}_{\text {Aeq }}$ was introduced to a music venue. During the evaluation period, there was less variation in the sound levels compared to the period before the limit was introduced and most events fell within $3 \mathrm{~dB}$ of the $98 \mathrm{~dB} \mathrm{~L}_{\text {Aeq }}$ level, suggesting that the venue sound engineers may have subconsciously treated it as a 'target' rather than a limit. 
One solution may be to implement a staged approach to sound levels as a way of encouraging a variety of sound levels across events. In the German standard, for example, there is an upper limit of $99 \mathrm{~dB} \mathrm{~L}_{\text {Aeq }}$ but a lower limit of $95 \mathrm{~dB} \mathrm{~L}_{\text {Aeq }}$ (with less onerous concomitant requirements) is also provided (Deutsches Institut für Normung, 2007).

\section{Real-time sound level monitoring}

It is essential that lower sound levels are verified using real-time sound level monitoring to provide the sound engineer with objective measurements that can be acted upon immediately to ensure that hazard substitution is in fact occurring. The most appropriate timeframe for measuring and monitoring sound levels is an open question. The various regulations in Table 1 stipulate timeframes ranging from $1 \mathrm{~min}$ to $4 \mathrm{~h}$ and further research is needed to better understand the most appropriate duration from an operator point of view. In any case, awareness of the sound level at any point in time (irrespective of the measurement timeframe), should help to prevent the typical increase in sound levels that occurs over the course of an evening at a rate of roughly $3 \mathrm{~dB}$ per $\mathrm{h}$ (Williams et al., 2010; Gjestland and Tronstad, 2017; Welch and Fremaux, 2017b). There is speculation that temporary threshold shift (TTS) of both audience members and staff can result in impaired loudness perception resulting in an increase in sound levels (Fortin and Hétu, 1994; Welch and Fremaux, 2017a), and objective monitoring would go some way towards counteracting this effect.

Some regulations require that real-time sound levels are visible to the audience and that records of measurements are retained for inspection at a later date. However, displaying levels to audience members could encourage interference with the measurement microphone (if accessible) and lead to spurious measurements. There is also a risk that the displayed sound levels will be misinterpreted by the audience-because they are unlikely to be familiar with the $\mathrm{L}_{\text {Aeq }}$ designation, and may mistakenly believe that $100 \mathrm{~dB} \mathrm{~L}_{\mathrm{Aeq}}$ is 'too low for a rock concert.' Despite the additional cost and complexity associated with record retention, it has considerable appeal not only for enforcement officers and researchers, but also venue operations. Having a historical record of sound levels would enable venues to keep track of their sound levels and evaluate how best to manage them. The Dutch approach, in which data are gathered and analysed centrally, offers both venue managers and enforcement authorities access to the same data. This model would enable a framework whereby compliance is enforced through a combination of retrospective analysis, random venue checks, and regular calibration of measurement equipment.

\section{Engineering controls}

\section{Restriction of access to loudspeakers}

Where possible, entertainment venues should prevent audience members from being in close proximity to loudspeakers, where sound levels are at their highest. Speaker placement can be optimized to achieve efficient and consistent delivery of sound to larger audiences without over-exposing audience members closest to the stage, although in smaller venues, low ceiling height and limited floor space may constrain the options with respect to loudspeaker placement. In these cases, finding sufficient space to insert a barrier between the audience and loudspeakers may be difficult.

\section{Provision of access to quiet respite areas}

Where possible, entertainment venues should provide audience members with a quiet zone or rest area where sound levels are considerably lower than in the main performance area, and ideally below $85 \mathrm{~dB} \mathrm{~L}_{\text {Aeq. }}$. The area should be easily accessible and indicated with clearly displayed signs. Although spending some time in a rest area where the sound level is lower will reduce overall exposure, the risk reduction effect will be minimal because high sound levels dominate the exposure calculation. For example, if a person is in a venue where the sound level is $100 \mathrm{~dB} \mathrm{~L}_{\text {Aeq }}$ for $2 \mathrm{~h}$, their exposure will be $8 \mathrm{~Pa}^{2} \mathrm{~h}$ (or 8 times the typical workplace noise exposure standard, $85 \mathrm{~dB} \mathrm{~L}_{\text {Aeq,8h }}=1 \mathrm{~Pa}^{2} \mathrm{~h}$ ). If they move to a rest area for 15 of the $120 \mathrm{~min}$, their overall exposure drops slightly to $7.03 \mathrm{~Pa}^{2}$ h. For exposure to drop below $1 \mathrm{~Pa}^{2} \mathrm{~h}$, a person would need to spend virtually all of their time in the rest area (108 of the $120 \mathrm{~min}$ ) and only $12 \mathrm{~min}$ at $100 \mathrm{~dB} \mathrm{~L}_{\text {Aeq }}$.

\section{Administrative controls}

\section{Provision of warnings}

Given the acknowledgment that specified sound limits cannot be regarded as 'safe' it is imperative that people who attend entertainment venues are informed of the potential risk to their hearing. There are several communication channels that could be used for the provision of this information to audience members, including during event promotion, at ticket purchase points, on tickets themselves, on entry to the venue and within the venue itself. Information about sound levels should be accompanied by access to advice about how to mitigate potential risks, 
including the use of hearing protection, limiting exposure time and use of 'quiet spaces' where relevant.

\section{Personal protective equipment}

\section{Provision of earplugs}

Personal protective equipment is regarded as a measure of last resort in the hierarchy of risk management controls, and the same principle applies in recreational settings. Knowing that high sound levels at entertainment venues cannot be eliminated entirely and that most venue attendees will not choose to spend their entire evening in a quiet rest area, attendees will likely be subject to at least some degree of risk, and it is therefore incumbent on venues to make protective equipment, such as earplugs, available to them. Research shows that earplugs are effective in reducing symptoms of hearing damage, such as tinnitus and TTS in those attending loud music events (Opperman et al., 2006; Ramakers et al., 2016). Ideally, high-fidelity earplugs should be provided either at cost price or at no cost since the availability of free earplugs has been shown to encourage usage among concert attendees (Cha et al., 2015) and the relatively flat frequency response of these earplugs means that they are usually more acceptable for music venue attendees (Beach et al., 2010; Bockstael et al., 2015). To facilitate uptake, venues should use signs and other forms of communication to ensure that audience members are aware that earplugs are available and the locations at which they can be obtained.

\section{Discussion}

Managing the risk of hearing damage for audience members attending entertainment venues is a complex issue that involves a range of stakeholders. As noted by previous authors, regulations alone are not enough to eliminate the risk to hearing health at entertainment venues and must be part of a larger solution (Rawool, 2012) but they have the potential to contribute to a significant change in this area. If music venues become more regulated, hearing-related measures, such as reduced sound levels, regular earplug use, and access to respite areas will start to become 'normalized'. Currently, there are strong cultural norms surrounding loud music (Welch and Fremaux, 2017b; Manchaiah et al., 2018) and also social norms that govern the behaviour of attendees in music venues (Chung et al., 2005; Goggin et al., 2008). These norms mean that high-intensity sound levels are expected and accepted, and protective behaviours are frowned upon. These norms exert a powerful influence, not only on young people who attend music venues, but also sound engineers and venue operators, making it very difficult to change attitudes and motivate behaviour change (Landälv et al., 2013; Widén, 2013). However, as regulation because more widespread, and the number of compliant venues increases, hearing-health practices will become more common. The benefits will be observed not only in individual venues, but in the creation of new norms, in which hearing-protective behaviours become acceptable practice. In time, these new norms could become powerful motivators to encourage behavioural change and ultimately a cultural shift towards entertainment venues that value and protect the hearing of all who enter them.

\section{Acknowledgements}

We thank Thais Morata for her assistance. All authors contributed substantially to the work and approved the final version of the manuscript. They also agree to take responsibility for the work.

\section{Funding}

The authors acknowledge the financial support of the Australian Government Department of Health, Department of Industry and Science, and the HEARing CRC, established under the Australian Government's Cooperative Research Centres (CRC) Program. The CRC Program supports industry-led collaborations between industry, researchers and the community.

\section{References}

Agenzia Nazionale per la Protezione dell'Ambiente. (2001) Regolamento recante norme per la determinazione dei requisiti acustici delle sorgenti sonore nei luoghi d'intrattenimento danzante e di pubblico spettacolo e nei pubblici esercizi. Available at http://www.isprambiente. gov.it/contentfiles/00003500/3530-manuali-2001-05. pdf/. Accessed 8 November 2019.

Beach EF, Gilliver M. (2019) Time to listen: most regular patrons of music venues prefer lower volumes. Front Psychol; 10: 607.

Beach E, Williams W, Gilliver M. (2010) Hearing protection for clubbers is music to their ears. Health Promot J Aust; 21 : 215-21.

Blesser B. (2007) The seductive (yet destructive) appeal of very loud music. eContact!, 9.4. Available at http://cec.concordia. ca/econtact/9_4/blesser.html. Accessed 8 November 2019.

Bockstael A, Keppler H, Botteldooren D. (2015) Musician earplugs: appreciation and protection. Noise Health; 17 : 198-208.

Boyle T. (2008) Health and safety: risk management. Leicester: IOSH Services Ltd. 
Cercle Bruit. (2018) Faktenblatt SLV und V-NISSG. Available at http://www.schallundlaser.ch/1_de/pdf/newsletter_ faktenblatt/Faktenblatt \%20SLV\%20und \%20V-NISSG_ DE.pdf. Accessed 8 November 2019.

Cha J, Smukler SR, Chung Y et al. (2015) Increase in use of protective earplugs by Rock and Roll concert attendees when provided for free at concert venues. Int J Audiol; 54: 984-6.

Chung JH, Des Roches CM, Meunier J et al. (2005) Evaluation of noise-induced hearing loss in young people using a webbased survey technique. Pediatrics; 115: 861-7.

City and County of San Francisco. (2002) Police code. Available at https://archive.org/stream/gov.ca.sf.police/ca_sf_police_ djvu.txt. Accessed 8 November 2019.

City of Minneapolis. (2014) Minneapolis Code of Ordinances 364.115. Available at http://www.minneapolismn.gov/ www/groups/public/@clerk/documents/webcontent/ wcms1p-121545.pdf. Accessed 8 November 2019.

Czech Republic. (2011) Regulation on the protection of health from the adverse effects of noise and vibrations. Available at https://aplikace.mvcr.cz/sbirka-zakonu/. Accessed 8 November 2019.

Departement Leefmilieu Natuur en Energie. (2016) Technische handleiding geluidsnormen voor muziekactiviteiten. Available at https://www.vlaanderen.be/nl/publicaties/detail/technische-handleiding-nieuwe-geluidsnormen-voormuziekactiviteiten-1. Accessed 8 November 2019.

Deutsches Institut für Normung. (2007) DIN 15905-5: Event Technology-Sound Engineering-Part 5: Measures to prevent the high-frequency exposure of electroacoustic sound systems.

European Parliament and Council. (2003) Directive 2003/10/ EC of the European Parliament and of the Council on the minimum health and safety requirements regarding the exposure of workers to the risks arising from physical agents (noise). Off J Eur Union; 46: 38-44.

Flemish Government. (2013) Vlaams Reglement betreffende de Milieuvergunning (VLAREM II). Brussels Available at https://navigator.emis.vito.be/mijn-navigator? woId=9487. Accessed 8 November 2019.

Fortin M, Hétu R. (1994) Characterization of occupational sound exposure of professional involved in highly amplified music reproduction. Can Acoust; 22: 87-8.

Gilles A, Thuy I, De Rycke E et al. (2014) A little bit less would be great: adolescents' opinion towards music levels. Noise Health; 16: 285-91.

Gjestland T, Tronstad TV. (2017) The efficacy of sound regulations on the listening levels of pop concerts. J Occup Environ Hyg; 14: 17-22.

Goggin LS, Eikelboom RH, Edwards GS et al. (2008) Noise levels, hearing disturbances, and use of hearing protection at entertainment venues. Aust N Z J Audiol; 30: 50-8. doi:10.1375/audi.30.1.50

Government of the Brussels-Capital Region. (2017) Besluit van de Brusselse Hoofdstedelijke Regering tot vaststelling van de voorwaarden voor het verspreiden van versterkt geluid in voor publiek toegankelijke inrichtingen. Available at http:// www.ejustice.just.fgov.be/cgi_loi/change_lg.pl?language $=$ n $1 \& l a=N \& c n=2017012632 \&$ table_name $=$ wet. Accessed 8 November 2019.

Hanson DR, Fearn RW. (1975) Hearing acuity in young people exposed to pop music and other noise. Lancet; 2: 203-5.

Health and Safety Executive. Noise. Available at http://www. hse.gov.uk/event-safety/noise.htm. Accessed 8 November 2019.

Johnson O, Andrew B, Walker D et al. (2014) British university students' attitudes towards noise-induced hearing loss caused by nightclub attendance. J Laryngol Otol; 128: 2934; quiz 33-4.

Kraaijenga VJC, van Munster JJCM, van Zanten GA. (2018) Association of behavior with noise-induced hearing loss among attendees of an outdoor music festival: a secondary analysis of a randomized clinical trial. JAMA Otolaryngol Head Neck Surg; 144: 490-7.

Landälv D, Malmström L, Widén SE. (2013) Adolescents' reported hearing symptoms and attitudes toward loud music. Noise Health; 15: 347-54.

Leefmilieu Brussel. (2017) Versterkt geluid: Gids voor organisatoren van evenementen en uitbaters van etablissementen. Available at https://leefmilieu.brussels/ themas/geluid/versterkt-geluid/versterkt-geluid-verspreidenregels-brussel. Accessed 8 November 2019.

Lindgren F, Axelsson A. (1983) Temporary threshold shift after exposure to noise and music of equal energy. Ear Hear; 4: 197-201.

Manchaiah V, Zhao F, Oladeji S et al. (2018) Examination of previously published data to identify patterns in the social representation of "Loud music" in young adults across countries. Noise Health; 20: 16-22.

McGinnity S, Mulder J, Beach EF et al. (2018) Investigating the use of sound level management software in live indoor music venues. Paper presented at the Conference on MusicInduced Hearing Disorders, Chicago, USA.

Mercier V, Hohmann BW. (2002) Is electronically amplified music too loud? What do young people think? Noise Health; 4: 47-55.

Meyer-Bisch C. (1996) Epidemiological evaluation of hearing damage related to strongly amplified music (personal cassette players, discotheques, rock concerts) - high-definition audiometric survey on 1364 subjects. Audiology; 35: 121-42.

Neitzel R, Fligor BJ. (2017) Determination of risk of noiseinduced hearing loss due to recreational sound: review. Geneva: World Health Organisation.

NIOSH. (1998) Occupational noise exposure: revised criteria. Cincinnati, OH: National Institute of Occupational Safety and Health. Available at https://www.cdc.gov/niosh/docs/98126/pdfs/98-126.pdf? id=10.26616/NIOSHPUB98126. Accessed 8 November 2019.

Norway. (2011) Musikkanlegg og helse: Veileder til arrangører og kommuner. Available at https:// helsedirektoratet.no/Lists/Publikasjoner/ 
Attachments/661/Musikkanlegg-og-helse-veiledertil-arrangorer-og-kommuner-IS-0327.pdf. Accessed 8 November 2019.

Opperman DA, Reifman W, Schlauch R et al. (2006) Incidence of spontaneous hearing threshold shifts during modern concert performances. Otolaryngol Head Neck Surg; 134: 667-73.

Parnell J, Hartcher A. (2017) Setting noise objectives for outdoor events at the Sydney Opera House. Paper presented at the Acoustics Australia Conference, Perth.

Presidente del Consiglio dei Ministri. (1999) Decreto del Presidente del Consiglio dei Ministri 16 Aprile1999, n.215. Regolamento recante norme per la determinazione dei requisiti acustici delle sorgenti sonore nei luoghi di intrattenimento danzante e di pubblico spettacolo e nei pubblici esercizi. Gazzetta Ufficiale della Repubblica Italiana. Available at www.gazzettaufficiale.it/eli/ id/1999/07/02/099G0206/sg. Accessed 8 November 2019.

Ramakers GG, Kraaijenga VJ, Cattani G et al. (2016) Effectiveness of earplugs in preventing recreational noiseinduced hearing loss: a randomized clinical trial. JAMA Otolaryngol-Head Neck Surg; 142: 551-8.

Rawool VW. (2012) Hearing conservation in occupational, recreational, educational, and home settings. New York: Thieme.

Republic of Austria. (2011) Lärmschutzrichtlinie für Veranstaltungen. Available at http://www. umweltbundesamt.at/fileadmin/site/publikationen/ REP0310.pdf. Accessed 8 November 2019.

Republic of Nicaragua. (2005) Ley especial de delitos contra el medio ambiente y los recursos naturales. Available at https:// www.poderjudicial.gob.ni/pjupload/spenal/pdf/2005_ley03. pdf. Accessed 8 November 2019.

Republic of Trinidad and Tobago. (2000) Environmental Management Act. Available at http://rgd.legalaffairs.gov.tt/ Laws2/Alphabetical_List/lawspdfs/35.05.pdf. Accessed 8 November 2019.

République Française. (2017) Décret no 2017-1244 du 7 août 2017 relatif à la prévention des risques liés aux bruits et aux sons amplifiés. Available at https://www.legifrance.gouv. fr/eli/decret/2017/8/7/SSAP1700132D/jo/texte. Accessed 8 November 2019.
State of Delaware. (1982) 1149 Regulations Governing the Control of Noise. Available at http://regulations.delaware. gov/AdminCode/title7/1000/1100/1149.shtml. Accessed 8 November 2019.

Strasser H, Irle H, Legler R. (2003) Temporary hearing threshold shifts and restitution after energy-equivalent exposures to industrial noise and classical music. Noise Health; 5: 75-84.

Sweden. (2005) Höga ljudnivåer. The National Board of Health and Welfare (SOSFS). Available at http://www.alvesta.se/con tentassets/3f44be7e6ca2406ea3ac952a0cde8d87/sos-radom-hoga-ljudnivaer.pdf. Accessed 8 November 2019.

Swiss Confederation. (2012) Ordinance on the protection of audiences from exposure to hazardous sound levels and laser beams. Available at https://www.admin.ch/opc/en/ classified-compilation/20022391/index.html. Accessed 8 November 2019.

United Mexican States. (2013) Acuerdo por el que se modifica el numeral 5.4 de la Norma Oficial Mexicana Nom081-Semarnat-1994, Que establece los límites máximos permisibles de emisión de ruido de las fuentes fijas y su método de medición. Secretariat of the Environment and Natural Resources. Available at www.ordenjuridico. gob.mx/Documentos/Federal/wo89474.doc. Accessed 8 November 2019.

Vereniging Nederlandse Poppodia en Festivals, Ministerie van Volksgezondheid Welzihn en Sport, \& al., e. (2018) Derde Convenant Preventie Gehoorschade Verstekte Muziek. Available at https://vnpf.nl/media/files/derde-convenantpreventie-gehoorschade-05122018-00000002.pdf. Accessed 8 November 2019.

Welch D, Fremaux G. (2017a) Understanding why people enjoy loud sound. Semin Hear; 38: 348-58.

Welch D, Fremaux G. (2017b) Why do people like loud sound? A qualitative study. Int J Environ Res Public Health; 14: 908. doi:10.3390/ijerph14080908

Widén SE. (2013) A suggested model for decision-making regarding hearing conservation: towards a systems theory approach. Int J Audiol; 52: 57-64. doi:10.3109/14992027.20 12.728724

Williams W, Beach EF, Gilliver M. (2010) Clubbing: the cumulative effect of noise exposure from attendance at dance clubs and night clubs on whole-of-life noise exposure. Noise Health; 12: 155-8. 